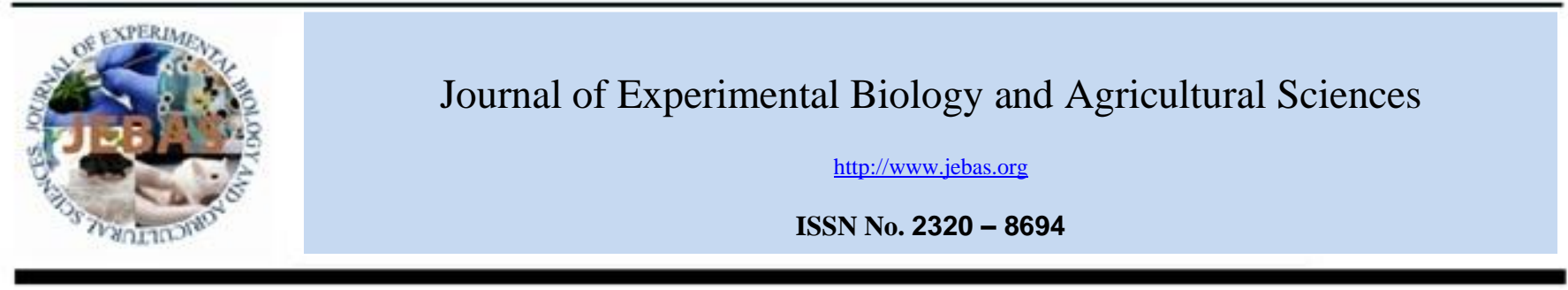

\title{
OPTIMIZING YIELD AND FIBER QUALITY OF COTTON UNDER MEDITERRANEAN ENVIRONMENT: MANAGING NITROGEN AND POTASSIUM NUTRITION
}

\author{
Gormus $\mathrm{O}^{1}$, EL Sabagh $\mathrm{A}^{2, *}$ and Islam $\mathrm{M} \mathrm{S}^{3}$
}

${ }^{1}$ Department of Field Crops, Faculty of Agriculture, Cukurova University, Turkey

${ }^{2}$ Department of Agronomy, Faculty of Agriculture, Kafrelsheikh University, Egypt.

${ }^{3}$ Department of Agronomy, Hajee M. Danesh Science and Technology University, Bangladesh

Received - August 30, 2016; Revision - September 13, 2016; Accepted - October 01, 2016

Available Online - October 07, 2016

DOI: http://dx.doi.org/10.18006/2016.4(5S).572.580

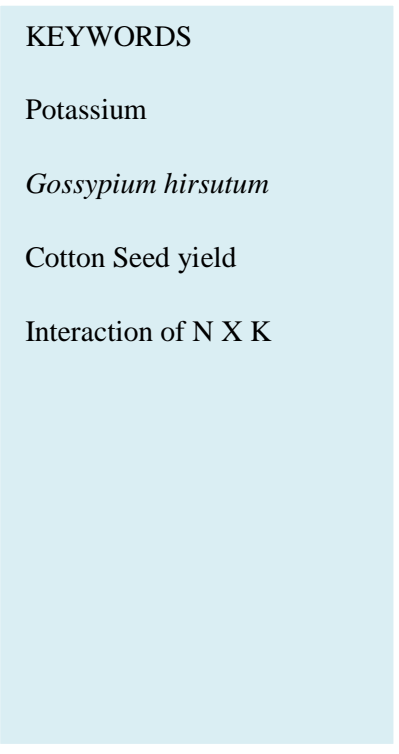

\begin{abstract}
Effective management strategies for nitrogen $(\mathrm{N})$ and potassium $(\mathrm{K})$ fertilizer are important to ensure optimum yield and fiber quality of cotton production. The aim of this research was to study the influence of nitrogen and potassium application on yield and fiber quality of cotton. Study was conducted in a randomized blocks in a factorial design with three replicates. The nitrogen treatments $(0$, $\left.60,120,180,240 \mathrm{~kg} \mathrm{ha}^{-1}\right)$ and five $\mathrm{K}_{2} \mathrm{O}$ rates $\left(0,50,100,150\right.$, and $\left.200 \mathrm{~kg} \mathrm{ha}^{-1}\right)$ are used in this study. Among the various tested combinations, the best combinations are $180 \mathrm{~kg} \mathrm{~N}^{-1}$ along with $150 \mathrm{~kg} \mathrm{~K}$ $\mathrm{ha}^{-1}$ and it produced the greatest seed cotton yieldand gin turnout. After 120 days of plantation $72 \%$ reduction in the dry weight was reported in the nitrogen deficient treatment and these plants produced only 17 bolls per plant and it was significantly different ( 25 bolls) than the plant treated by $180 \mathrm{~kg} \mathrm{~N} \mathrm{ha}$ 1. Significant and negative correlations were reported between boll number per plant and micronaire and total dry matter yield were found at $\mathrm{K}$ fertilization treatments. Positive and significant correlations were determined between gin turnout and micronaire and between fiber strength and total biomass production at $\mathrm{N}$ fertilization. The highest fiber strength was recorded in the plant treated by the combination of 240 $\mathrm{kg} \mathrm{ha}^{-1}$ nitrogen and $50 \mathrm{~kg} \mathrm{ha}^{-1}$ potassium. For fiber length and fiber strength, no significant differences were reported among the various treatments of potassium. From the results of this study it can be concluded that combination of $180 \mathrm{~kg} \mathrm{ha}^{-1}$ nitrogen and $100 \mathrm{~kg} \mathrm{ha}^{-1}$ potassium are suitable for the production of cotton crop.
\end{abstract}

* Corresponding author

E-mail: ayman.elsabagh @agr.kfs.edu.eg (Sabagh A)

Peer review under responsibility of Journal of Experimental Biology and Agricultural Sciences.

Production and Hosting by Horizon Publisher India [HPI] (http://www.horizonpublisherindia.in/).

All rights reserved.
All the article published by Journal of Experimental Biology and Agricultural Sciences is licensed under a Creative Commons Attribution-NonCommercial 4.0 International License Based on a work at www.jebas.org.

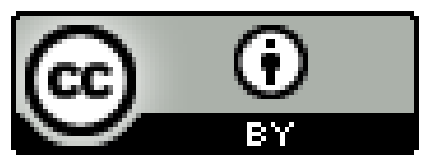




\section{Introduction}

Availability of nitrogen affect the indeterminate growth of Cotton's (Gossypium sps.), regular supply of nitrogen are the basic need of for the cotton production. Since cotton production covers a wide range of environments and economic circumstances, hence yields and nutritional requirements of this vary greatly. Depending on the varietal differences agronomic practices and input requirements are also varies. Nitrogen has to be applied under all set of growing conditions because nitrogen requirements of cotton plant are different at various stages of development. A wide variety of experiments on the effect of fertility on cotton crop have been conducted worldwide under various soils conditions and fertilizer sources and with different rates and varieties (Fritschi et al., 2003; Reddy et al., 2004; Read et al., 2006). Like nitrogen fertilizer, continues removal of potassium fertilizer was also reported and a reduction in cotton productivity was reported because cotton crop appears to be more sensitive to $\mathrm{K}$ deficiencies (Cope, 1981).

Remarkable improvements in cotton yield and quality resulting from potassium input were reported by Mullins \& Burmester (1991) and Pettigrew et al. (2005). While the $\mathrm{N}$ and $\mathrm{K}$ requirements are quite well disseminated to growers and among these two, $\mathrm{K}$ received less attention. To manage the efficacy of nitrogen fertilizer adequate supply of potassium is required because a strong interaction between nitrogen and potassium was reported by Johnston \& Milford (2012). By understanding how nutrients work together, a better strategy can be developed for improving the productivity and deciding wiser farm investments. This will also help in minimizing the negative impacts of fertilizer. Knowledge of interactions among major plant nutrients is important in formulating balanced supply of fertilizers to crop plants. Studies with cotton have shown $\mathrm{N}$ and $\mathrm{K}$ to be sensitive nutrients and their potential interaction effects for profitable cotton production (Pettigrew et al., 2005; Kumar et al., 2011). Objective of this study was to determine the effect of nitrogen and potassium fertilizers on yield and quality parameters of cotton crop under Mediterranean environmental conditions.

\section{Materials and Methods}

The experiment was carried out at the Research Farm, Cukurova University, Adana, the Eastern Mediterranean region of Turkey. Study area was located between $37^{\circ} 00^{\prime} 02^{\prime \prime} \mathrm{N}$ latitude and $35^{\circ} 18^{\prime} 00^{\prime \prime}$ E longitude at $33 \mathrm{~m}$ altitude. Study was conducted for two successive growing seasons of 2010 and 2011, using the cotton cultivar SG-125 (Gossypium hirsutum L.). The soil of the experimental plots is classified as a Vertisol (chromoxeret) and has relatively high clay content with the predominant clay minerals smectite and kaolinite. The climate of the experimental site is typically Mediterranean with May-October growth season. Annual rainfall was reported between $50.3 \mathrm{~mm}$ (2010) to $88.1 \mathrm{~mm} \mathrm{(2011)} \mathrm{and} \mathrm{mean}$ monthly temperatures ranging between $27.6^{\circ} \mathrm{C}$ and $36.1^{\circ} \mathrm{C}$ and between $26.7^{\circ} \mathrm{C}$ and $34.71^{\circ} \mathrm{C}$ in 2010 and 2011 , respectively (data not shown). Composite soil samples were taken from trial site at depths $0-30 \mathrm{~cm}$ in both seasons. The soil was clay loam in texture, nonsaline, slighly alkaline in reaction, and highly calcerous. Soil properties of the experimental site are given in Table 1.

Table 1 Soil characteristics of the experimental site.

\begin{tabular}{|lll|}
\hline Soil analysis & $\mathbf{2 0 1 0}$ & $\mathbf{2 0 1 1}$ \\
\hline Organic matter $(\%)$ & 2.05 & 2.12 \\
\hline $\mathrm{CaCO}_{3}(\%)$ & 24.3 & 24.5 \\
\hline Sand $(\%)$ & 12.9 & 14.3 \\
\hline Clav $(\%)$ & 48.2 & 54.1 \\
\hline Loam (\%) & 33.0 & 34.5 \\
\hline Texture & Clav loam & Clav loam \\
\hline pH & 7.5 & 7.6 \\
\hline Available nitrogen $\left(\mathrm{mg} \mathrm{kg}^{-1}\right)$ & 34 & 22 \\
\hline Available phosphorus $\left(\mathrm{mg} \mathrm{kg}^{-1}\right)$ & 13.4 & 11.8 \\
\hline Available potassium $\left(\mathrm{mg} \mathrm{kg}^{-1}\right)$ & 178 & 192 \\
\hline Total sulfur $\left(\mathrm{mg} \mathrm{kg}^{-1}\right)$ & 23.0 & 21.0 \\
\hline
\end{tabular}

The experimental design consisted of randomized blocks in a factorial arrangement with three replicates. Different fields were used every year and new randomization was carried out every year and the same plots were not used next year. Five level of nitrogen viz. $0,60,120,180$ and $240 \mathrm{~kg} \mathrm{ha}^{-1}$, corresponding to N0, N60, N120, N180 and N240 kg N ha ${ }^{-1}$ ) and $\mathrm{K}$ i.e. $0,50,100,150$ and $200 \mathrm{~kg} \mathrm{ha}^{-1}$ corresponding to $\mathrm{K} 0, \mathrm{~K} 50, \mathrm{~K} 100, \mathrm{~K} 150$ and $\mathrm{K} 200 \mathrm{~kg} \mathrm{~K}$ ha-1) were used in this study. The rate of $\mathrm{N}$ and $\mathrm{K}$ were established taking into account the results of previous studies conducted in Turkey's cotton regions (Colakoğlu, 1980; Tozan, 1990; Gormus \& Yucel, 2002). The $\mathrm{N}$ and $\mathrm{K}$ were applied as ammonium nitrate and potassium sulfate in three equal splits viz. 1/3 at time of planting, $1 / 3$ at early square and $1 / 3$ at early bloom.

A buffer zone of 2 rows spacing was provided between each plot. Plants were planted on 10 May 2010 and 28 April in 2011. Plots have 4 rows of $10 \mathrm{~m}$ length with a $0.7 \mathrm{~m}$ distance. All plots received $70 \mathrm{~kg}$ triple superphosphate per hectare as a basal rate. Standard cultural practices such as pest management, weeding and irrigation were carried out as recommended for the study area. After 120 days of planting (DAP) plant dry matter (biomass) was measured. Five plants were selected from the inner two rows of each plot and were sampled; all the selected samples were partitioned into vegetative and reproductive organs. All samples were dried at $70^{\circ} \mathrm{C}$ for $48 \mathrm{~h}$, all the dried samples were weighed and dry matter were estimated on the basis of per-unit-land-area. Ten plants were selected from each plot to record the number of open bolls at harvest. Seed cotton yield was determined from the two inside rows from a 4 row plots. 
Table 2 Mean squares according to analysis of variance of yield, yield components and fiber traits.

\begin{tabular}{|c|c|c|c|c|c|c|c|c|c|}
\hline S.O.V & df & $\begin{array}{l}\text { Total dry } \\
\text { matter at } \\
120 \text { DAP }\end{array}$ & $\begin{array}{c}\text { Open } \\
\text { bolls } \\
\text { plant }^{-1}\end{array}$ & $\begin{array}{c}\text { Boll } \\
\text { weight }\end{array}$ & $\begin{array}{l}\text { Gin } \\
\text { turnout }\end{array}$ & $\begin{array}{c}\text { Seed } \\
\text { cotton } \\
\text { yield }\end{array}$ & $\begin{array}{l}\text { Fiber } \\
\text { length }\end{array}$ & $\begin{array}{c}\text { Fiber } \\
\text { strength }\end{array}$ & Micronaire \\
\hline Replicate & 2 & 1573.74 & 133.9 & 0.899 & 1.053 & 9235.3 & 0.038 & 1.851 & 0.183 \\
\hline Year $(Y)$ & 1 & $22841.3 * *$ & 5928 *** & $23.537 * *$ & $4.824 *$ & $8939 * *$ & 52.819 & $100.8 * *$ & $2.089 *$ \\
\hline $\mathrm{N} \operatorname{rate}(\mathrm{N})$ & 4 & $541112 . * *$ & $466.5 * *$ & $9.239 * *$ & $29.13 * *$ & $13856 * *$ & $3.953 *$ & $8.460 *$ & $1.650 * *$ \\
\hline $\mathrm{YXN}$ & 4 & $17265.8 * *$ & $66.04 *$ & $2.462 *$ & $4.082 * *$ & 3015 .** & 2.110 & 1.171 & 0.106 \\
\hline $\mathrm{K}$ rate $(\mathrm{K})$ & 4 & $21803.0 * *$ & $66.58 *$ & $3.698 * *$ & $3.185 * *$ & 8015.** & 1.622 & 0.106 & $0.451 * *$ \\
\hline Y X K & 4 & $518.65 * *$ & 24.77 & 1.373 & 0.370 & 813.1 & 0.247 & 0.337 & 0.023 \\
\hline $\mathrm{NXK}$ & 16 & $1432.318^{* *}$ & 28.36 & $1.909 * *$ & $4.535 * *$ & $1790 . * *$ & 2.015 & $5.087 *$ & $0.323 * *$ \\
\hline YXNXK & 16 & $1092.49 * *$ & $42.55 *$ & $1.874 * *$ & $1.870 * *$ & 996.1 & 0.382 & 0.361 & 0.052 \\
\hline Error & 98 & 210.15 & 20.72 & 0.778 & 0.799 & 798.6 & 1.179 & 2.541 & 0.074 \\
\hline
\end{tabular}

* Significant at $\mathrm{P}<0.05$;**Significant at $\mathrm{P}<0.01$

At harvesting stage, 20 ready to harvest bolls from the two central rows were collected from each plot to determine boll weight, gin turnout and fiber properties. Average boll weight was calculated by dividing the total plant seed cotton yield with respected to number of bolls per plant. Fiber analysis was conducted by using High Volume Instrumentation (HVI) method. Data were analyzed by analysis of variance and regression analysis was performed. Means were compared using LSD at 5\% significance level. Appropriate regression model was selected on the basis of R2. The combined data showed interactions with year, thus, all the data are presented separately for each year.

\section{Results and Discussion}

Mean squares analysis of variance for yield, yield components and fiber traits are presented in Table 2. Significant effects were observed for total biomass, number of open bolls per plant, boll weight, gin turnout, cotton seed yield, fiber strength and micronaire. The main effects associated with $\mathrm{N}$ and $\mathrm{K}$ rate were significant for total biomass, number of open bolls per plant, boll weight, gin turnout, seed cotton yield and micronaire. Interactions between N X K have significant effect on the boll weight, gin turnout, seed cotton yield, fiber strength and micronaire. Further, interaction between Year $\mathrm{X} \mathrm{N}$ was also showing a significant effect on total biomass, number of bolls per plant, boll weight, gin turnout and seed cotton yield. Like nitrogen, interaction of Year X K also has significant effect on total biomass. Combination of all three factors (Year $\mathrm{X} \mathrm{N}$ X K rate) were found significant for total biomass, number of open bolls per plant, boll weight and gin turnout.

\subsection{Effect of fertilization of Total dry matter}

Production of total dry matter (TDM) was significantly increased with increasing $\mathrm{N}$ fertilizer up to N180 and afterward a remarkable reduction was reported up to N240 in both years. Improvement of TDM was always higher in 2011 as compared to 2010 for all treatments (Table 3). Incase in the rate of $\mathrm{K}$ fertilizer application caused significant improvement in the value of TDM and the highest value in 2010 was observed at K200. Similarly, improvement in TDM was also recorded in 2011 at K200 but it was not statistically different from the K150 (Table3). Similar results were also reported by Yang et al. (2016), who reported that $150 \mathrm{~kg} \mathrm{~K} \mathrm{ha}{ }^{-1}$ was the best application strategy for maximum aerial biomass of cotton. Significantly positive linear relationships existed between $\mathrm{N}$ and $\mathrm{K}$ rates and total biomass accumulations in both years (Figure. 2b) and also reported a correlations between total biomass accumulation and seed cotton yield $\left(\mathrm{r}=0.980^{* *}\right)$. These results are consistent with the findings of Makhdum et al. (2007) and Clement et al. (2013).

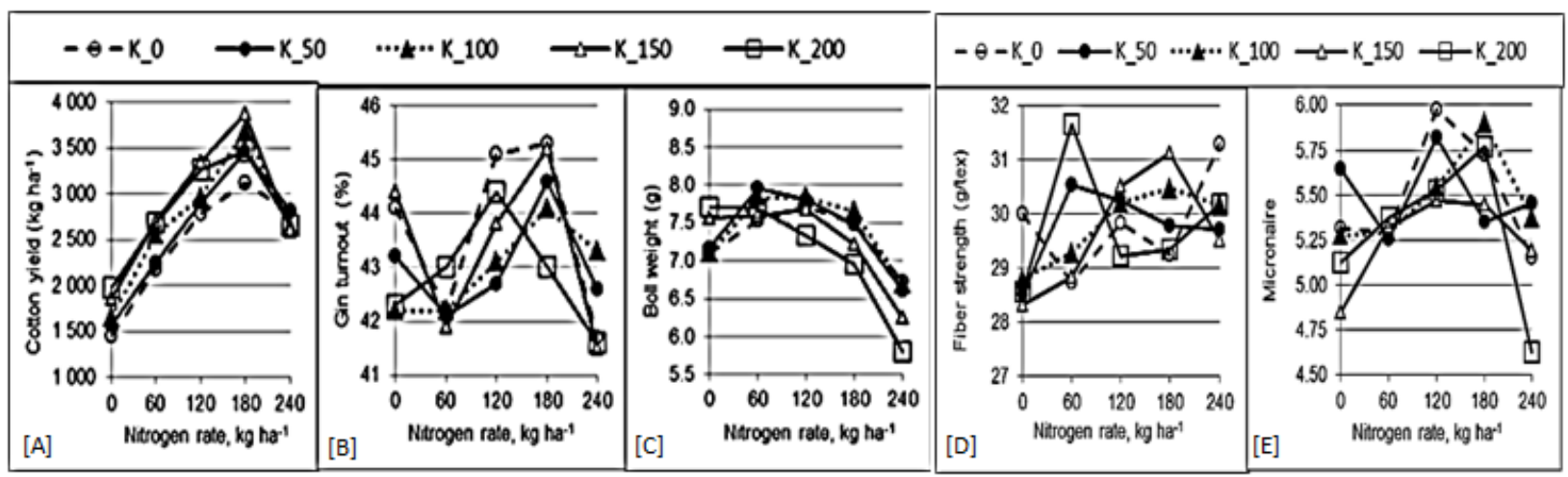

Figure 1 Interaction effects of $\mathrm{N}$ and $\mathrm{K}$ (over 2 years) on: a) cotton seed yield; b) gin turnout; c) boll weight; d) fiber strength and e) micronaire 
Table 3 Effects of $\mathrm{N}$ and $\mathrm{K}$ on total dry matter and yield components.

\begin{tabular}{|c|c|c|c|c|c|c|c|c|}
\hline & \multicolumn{2}{|c|}{$\begin{array}{l}\text { Total dry matter accum. } \\
\qquad\left(\mathrm{g} \mathrm{m}^{-2}\right)\end{array}$} & \multicolumn{2}{|c|}{ Open bolls plant ${ }^{-1}$} & \multicolumn{2}{|c|}{$\begin{array}{l}\text { Boll weight } \\
(\mathrm{g})\end{array}$} & \multicolumn{2}{|c|}{$\begin{array}{l}\text { Gin turnout } \\
(\%)\end{array}$} \\
\hline $\mathrm{N}$ rate $\left(\mathrm{kgha}^{-1)}\right.$ & 2010 & 2011 & 2010 & 2011 & 2010 & 2011 & 2010 & 2011 \\
\hline 0 & $475^{\mathrm{e}}$ & $464^{\mathrm{e}}$ & $10.7^{\mathrm{d}}$ & $22.1^{\mathrm{d}}$ & $6.5^{\mathrm{b}}$ & $7.2^{\mathrm{b}}$ & $42.8^{\mathrm{b}}$ & $42.4^{\mathrm{c}}$ \\
\hline 60 & $578^{\mathrm{d}}$ & $557^{\mathrm{d}}$ & $11.2^{\mathrm{d}}$ & $23.8^{\mathrm{cd}}$ & $7.1^{\mathrm{ab}}$ & $8.0^{\mathrm{a}}$ & $42.2^{\mathrm{bc}}$ & $43.7^{b}$ \\
\hline 120 & $641^{c}$ & $709^{c}$ & $14.1^{\mathrm{c}}$ & $27.7^{\mathrm{bc}}$ & $7.3^{\mathrm{a}}$ & $8.1^{\mathrm{a}}$ & $44.2^{\mathrm{a}}$ & $43.4^{\mathrm{b}}$ \\
\hline 180 & $810^{\mathrm{a}}$ & $816^{\mathrm{a}}$ & $21.3^{\mathrm{a}}$ & $30.2^{\mathrm{a}}$ & $7.2^{\mathrm{a}}$ & $7.5^{\mathrm{ab}}$ & $44.2^{\mathrm{a}}$ & $44.7^{\mathrm{a}}$ \\
\hline 240 & $687^{\mathrm{b}}$ & $767^{b}$ & $17.7^{\mathrm{b}}$ & $29.0^{\mathrm{b}}$ & $5.5^{\mathrm{c}}$ & $6.8^{\mathrm{b}}$ & $41.6^{\mathrm{c}}$ & $42.6^{\mathrm{c}}$ \\
\hline $\operatorname{LSD}_{(5 \%)}$ & 2.55 & 14.30 & 1.16 & 3.93 & 0.56 & 0.73 & 0.67 & 0.65 \\
\hline \multicolumn{9}{|l|}{ K rate $\left(\mathrm{kgha}^{-1}\right)$} \\
\hline 0 & $605^{\mathrm{e}}$ & $625^{\mathrm{c}}$ & $13.3^{\mathrm{c}}$ & 24.5 & 6.4 & $6.6^{\mathrm{b}}$ & 43.5 & 43.8 \\
\hline 50 & $622^{\mathrm{d}}$ & $646^{\mathrm{b}}$ & $14.1^{\mathrm{bc}}$ & 26.2 & 7.0 & $7.7^{\mathrm{a}}$ & 42.8 & 43.2 \\
\hline 100 & $640^{c}$ & $657^{\mathrm{b}}$ & $15.2^{\mathrm{ab}}$ & 28.8 & 7.0 & $7.7^{\mathrm{a}}$ & 42.7 & 43.3 \\
\hline 150 & $653^{\mathrm{b}}$ & $692^{\mathrm{a}}$ & $15.4^{\mathrm{a}}$ & 27.0 & 6.6 & $7.8^{\mathrm{a}}$ & 43.3 & 43.4 \\
\hline 200 & $671^{\mathrm{a}}$ & $693^{\mathrm{a}}$ & $15.9^{\mathrm{a}}$ & 29.4 & 6.4 & $7.7^{\mathrm{a}}$ & 42.7 & 43.0 \\
\hline $\operatorname{LSD}_{(5 \%)}$ & 2.55 & 14.30 & 1.16 & ns & ns & 0.73 & ns & ns \\
\hline
\end{tabular}

Means followed by the same letter are not significantly different at $P=0.05$

These results may be reported because of adequate supplies of $\mathrm{N}$ and $\mathrm{K}$ which has significant effect on plant dry matter production. Plants with low supply of these nutrients show lower dry matter production, which impacts the production and allocation of photosynthates to the reproductive organs. The way cotton plant allocate photosynthates between vegetative and fruit growth in response to $\mathrm{K}$ nutrition critically affect the cotton yield potential. Significant reductions in total dry matter production with nitrogen deficiency were reported by Lokhande \& Reddy (2015) and Fritschi et al. (2003). In this concern, another study revealed a significant effects of nitrogen sources and rates on dry matter in different crops and environments (EL Sabagh et al., 2016). Contradictory findings were reported by Pettigrew \& Meredith (1997) those who reported that total plant dry matter was not altered by $\mathrm{N}$ and $\mathrm{K}$ fertilization.

\subsection{Number of open bolls per plant}

Number of open bolls per plant increased significantly with increasing the rates of $\mathrm{N}$ application but this increment was reported only up to $\mathrm{N} 180 \mathrm{~kg} / \mathrm{ha}$ and thereafter sudden reduction was reported for both the years. The treatment containing N180 had statistically higher number of open bolls per plant (21.2 and 30.3) for both years, respectively (Table 3). Although number of bolls increased significantly with increasing rates of $\mathrm{K}$ fertilizer in 2010 but this improvement was not significantly different from 2011 (Table 3). A significant difference was reported between K150 and K200 treatments in case of open bolls per plant. Highest $\mathrm{N}$ rate reduced the number of open bolls; possibly because of high $\mathrm{N}$ levels in soil can cause excessive vegetative growth, which generally is detrimental to lint quality, and yield (McConnell et al., 1995). Boll number is closely connected with the formation of fruiting sites and nitrogen application could promote boll production, as evident from the significant relationship between the boll number per plant and $\mathrm{N}$ and $\mathrm{K}$ applications (Figure. 2c). No significant differences through $\mathrm{K}$ application were reported by Mert et al. (1999) and Karademir et al.
(2006). Zhao et al (2001) reported that declining trends under $\mathrm{K}$ deficient conditions for boll number and biomass similar to results of present study.

\subsection{Boll weight}

Statistically highest boll weights were reported in the plots receiving 60, 120 and $180 \mathrm{~kg} \mathrm{Nha}^{-1}$. Boll weights were found to increase by 9.2 to $11.1 \%$ with increasing $\mathrm{N}$ from 0 to $60 \mathrm{~kg}$ $\mathrm{ha}^{-1}$ in 2010 and 2011, respectively. Lowest boll weight was reported from the treatment containing N240 in both years but in 2011 no significant difference was reported between the treatment N0 and N240 (Table 3). Total boll weight was declined in N-deficient and N240 treatments because of less number of bolls produced and retained. $\mathrm{K}$ applications did not significantly affect boll weight in 2010, whereas it increased significantly in response to all $\mathrm{K}$ fertilizer applications over the K0 treatment in 2011 but no statistical differences were observed with the increment of $\mathrm{K}$ from K50 to K200 treatments. Nitrogen availability influenced biomass remobilization to the boll and affected boll growth. Decrease in boll weight in treatment containing $\mathrm{K} 0$ treatment was due to early abscission of leaves and carbohydrates accumulated in main stem leaves, so late formed bolls developed incompletely. Adding $\mathrm{K}$ increased maximum boll filling compared to treatments without $\mathrm{K}$ fertilizer, displaying the essential role of $\mathrm{K}$ in metabolism of carbohydrates, which is directly related to the fiber components and in remobilizing assimilates to the bolls. The increase in boll weight is correlated positively with the increase in K fertilization rate (Kumar et al., 2011).

\subsection{Gin turnout}

Result of gin turnout showed a significant improvement on the application of nitrogen. Among various tested $\mathrm{N}$ application rate highest gin turnout was reported from the treatment containing N120 and N180 and these two are significantly than the other N treatments and N240 which produced the lowest gin turnout. 
Table 4 Effects of $\mathrm{N}$ and $\mathrm{K}$ on yield and fiber quality traits.

\begin{tabular}{|c|c|c|c|c|c|c|c|c|}
\hline & \multicolumn{2}{|c|}{ Seed cotton yield $\left(\mathrm{kg} \mathrm{ha}^{-1}\right)$} & \multicolumn{2}{|c|}{ Fiber length (mm) } & \multicolumn{2}{|c|}{ Fiber strength $\left(\mathrm{g} \mathrm{tex}^{-1}\right)$} & \multicolumn{2}{|c|}{ Micronaire } \\
\hline $\mathrm{N}$ rate $\left(\mathrm{kg} \mathrm{ha}^{-1}\right)$ & 2010 & 2011 & 2010 & 2011 & 2010 & 2011 & 2010 & 2011 \\
\hline 0 & $1611^{\mathrm{e}}$ & $1796^{\mathrm{e}}$ & 29.5 & $27.7^{b}$ & $29.5^{b}$ & 28.1 & $5.44^{\mathrm{b}}$ & $5.04^{b}$ \\
\hline 60 & $2603^{\mathrm{d}}$ & $2345^{\mathrm{d}}$ & 30.3 & $28.9^{\mathrm{a}}$ & $30.6^{\mathrm{a}}$ & 28.9 & $5.43^{\mathrm{b}}$ & $5.18^{b}$ \\
\hline 120 & $3119^{\mathrm{b}}$ & $2988^{\mathrm{b}}$ & 29.4 & $28.9^{\mathrm{a}}$ & $30.5^{\mathrm{a}}$ & 29.4 & $5.70^{\mathrm{a}}$ & $5.64^{\mathrm{a}}$ \\
\hline 180 & $3674^{\mathrm{a}}$ & $3373^{\mathrm{a}}$ & 29.6 & $28.7^{\mathrm{a}}$ & $30.8^{\mathrm{a}}$ & 29.0 & $5.74^{\mathrm{a}}$ & $5.53^{\mathrm{a}}$ \\
\hline 240 & $2840^{\mathrm{c}}$ & $2573^{\mathrm{c}}$ & 29.7 & $28.2^{\mathrm{ab}}$ & $31.2^{\mathrm{a}}$ & 29.0 & $5.30^{\mathrm{b}}$ & $5.03^{b}$ \\
\hline \multicolumn{9}{|l|}{$\mathrm{K}$ rate $\left(\mathrm{kg} \mathrm{ha}^{-1}\right)$} \\
\hline 0 & $2497^{\mathrm{c}}$ & $2439^{c}$ & 29.5 & 28.2 & 30.6 & 29.0 & $5.35^{\mathrm{ab}}$ & 5.63 \\
\hline 50 & $2640^{c}$ & $2563^{b c}$ & 29.7 & 28.3 & 30.7 & 28.8 & $5.41^{\mathrm{a}}$ & 5.61 \\
\hline 100 & $2797^{\mathrm{b}}$ & $2611^{\mathrm{abc}}$ & 29.5 & 28.4 & 30.6 & 28.8 & $5.38^{\mathrm{a}}$ & 5.57 \\
\hline 150 & $2942^{\mathrm{ab}}$ & $2810^{\mathrm{a}}$ & 29.9 & 28.6 & 30.4 & 28.8 & $5.10^{\mathrm{c}}$ & 5.41 \\
\hline 200 & $2971^{\mathrm{a}}$ & $2653^{\mathrm{ab}}$ & 29.8 & 28.9 & 30.4 & 29.1 & $5.19^{\mathrm{bc}}$ & 5.38 \\
\hline $\mathrm{LSD}_{(5 \%)}$ & 14.55 & 186.2 & ns & ns & ns & ns & 0.18 & $\mathrm{Ns}$ \\
\hline
\end{tabular}

Means followed by the same letter are not significantly different at $P=0.05$

A similar trend was reported in 2011 also and the highest gin turnout was reported from the treatment $\mathrm{N} 180$ while lowest gin turnouts were reported from the N0 and N240 plots (Table 3). No significant effect of potassium fertilizer was reported on gin turnout at both years. In this respect, findings of present study are contradictory to the findings of Cassman et al. (1990) and Pettigrew (1999) those who reported a significant improvement in gin turnout on the application of potassium fertilizer.

\subsection{Seed cotton yield}

Like other treatments, here also highest seed cotton yield was reported on the application of nitrogen fertilizer@180 kg N $\mathrm{ha}^{-1}$ and this was significantly different from the all other nitrogen treatments while the lowest seed cotton yield was reported from the fertilizer rate $240 \mathrm{~kg} \mathrm{~N} \mathrm{ha}^{-1}$. These results are in agreement with the findings of Berberoğlu \& Karaltın (2001) and Karademir et al. (2006) those who reported a reduction in the seed cotton yield on the higher nitrogen fertilizer application. On the application of potassium, a significant improvement was reported in cotton seed yields and this improvement was reported maximum in the plots treated with 150 to $200 \mathrm{~kg} \mathrm{~K} \mathrm{ha}^{-1}$ as compared to the control, 50 and $100 \mathrm{~kg} \mathrm{ha}^{-1}$ treatments in 2010. In 2011, the trends are slightly different and all the tested level are almost at par to each other and no significant difference was reported among them (Table 4).

The higher seed cotton yield at N180 may be due to the cumulative effect of higher number of bolls per plant and continued availability of nutrients. Nutrient deficiency or insufficient supply of fertilizers might provide insufficient assimilates and this lead to the formation of square or small boll abortion and reduced number of boll per plant. According to $\mathrm{Wu}$ et al. (1998) nitrogen is an essential nutrient in producing plant dry matter, thus influencing boll development, increasing the number of bolls and weight. Production of photosynthates required for achieving higher yields becomes inefficient under $\mathrm{K}$ deficit conditions.
3.6 Fiber quality

With the exception of micronaire in 2010, fiber quality parameters was unaffected by the application of potassium, while fiber length and strength values were reported similar in both the studied years, respectively (Table 4). Results (except for micronaire) of present study were generally inconsistent with previous reports (Cassman et al., 1990; Pettigrew, 1999) those who reported a significant effect of $\mathrm{K}$ fertilization on lint quality. Fiber length and strength were significantly lower for the plots without nitrogen application as compared to the plots treated with nitrogen. Plot treated with $\mathrm{N} 60$ produced $1.2 \mathrm{~mm}$ longer fibers. Results of nitrogen application show similarly with the findings of Wang et al. (2012) those who suggested that both $\mathrm{N}$ deficiency and excess $\mathrm{N}$ can reduce the accumulation of nutrients in fiber cells which caused reduction in the fiber length. Similarly, Fritschi et al. (2003) reported increased fiber length with increasing $\mathrm{N}$ applications. According to Zhao et al. (2010) increase in the level of nitrogen can boost the fiber grade in terms of length and strength of cotton fiber.

Higher micronaire values were associated with the N120 and N180 while the lower values were reported from the treatment containing N60, N240 and N0. Higher K rates (150-200 kg ha ${ }^{-}$ $\left.{ }^{1}\right)$ resulted in reduction in micronaire values while the micronaire values of $\mathrm{K} 0, \mathrm{~K} 50$ and $\mathrm{K} 100$ are not statistically different in 2010 (Table 4). Fiber length response to fertilizer $\mathrm{N}$ at the experiment site supports results of previous research which suggest $\mathrm{N}$ applications have positive impact on fiber length (Bauer \& Roof, 2004; Read et al., 2006). In present study application of lower $\mathrm{N}$ given higher fiber length, it is possibly due to lower biomass production. Keller (1997) reported that the low micronaire was offset by a relatively high number of bolls per plant. Further, it was reported that fiber quality of was low for the plants grown under low $\mathrm{N}$ concentrations while it was reported higher on the optimum supply of nitrogen. Reason behind this may be a positive correlation between the nitrogen application and carbohydrate supply during boll development (Tewolde \& Fernandez, 2003). 

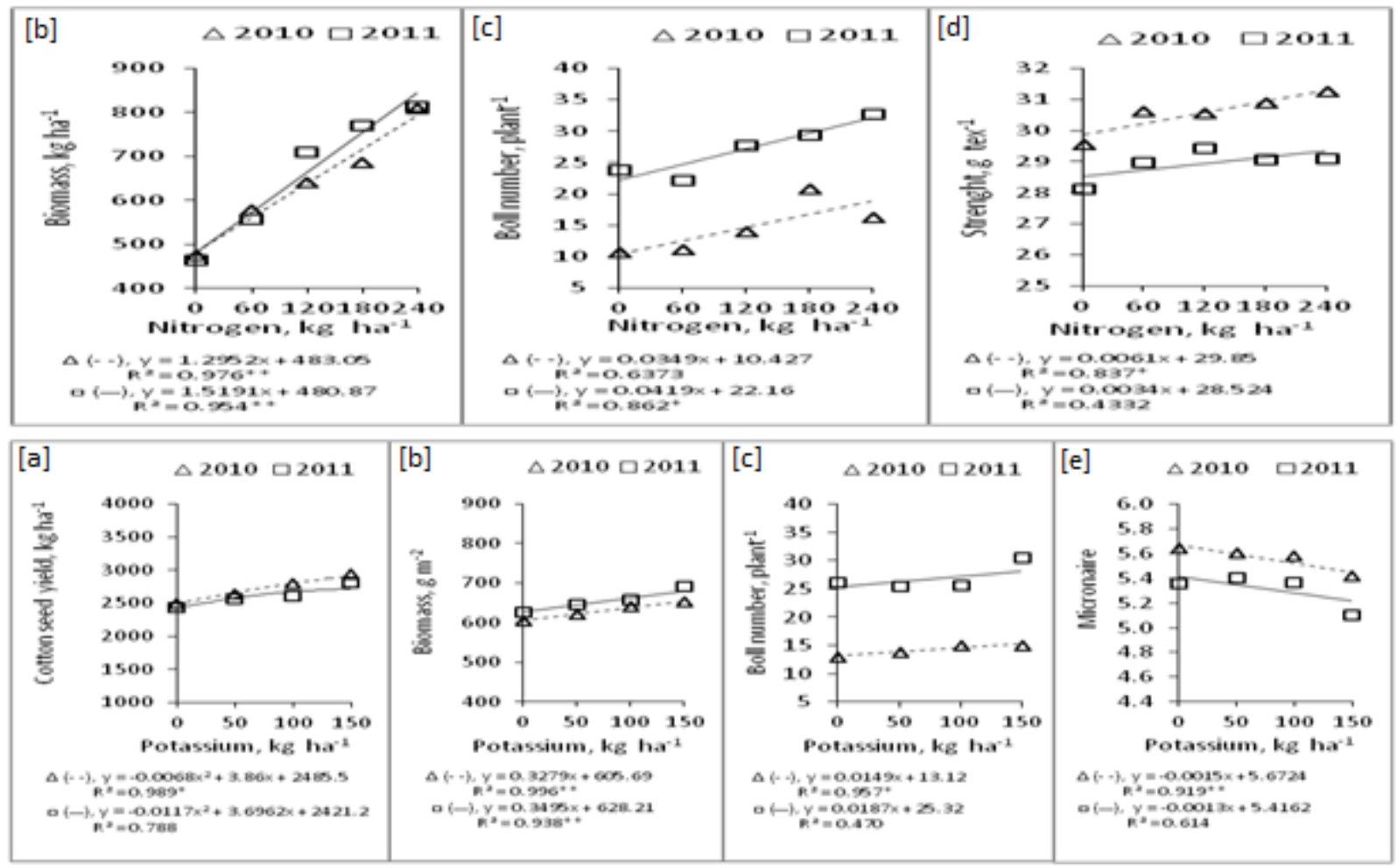

Figure 2 Relationships between K rates and (a) cotton seed yield; (b) biomass production; (c) boll number per plant and (e) micronaire; $\mathrm{N}$ rates and (b) biomass production; (c) boll number per plant; and (d) fiber strength during t2010 and 2011 years.

Cotton which is over-fertilized with $\mathrm{N}$ often has lower micronaire because it creates a condition of low carbohydrate in relation to boll demand. Bauer \& Roof (2004) and Read et al. (2006) reported that N-deficient can reduced fiber length, strength and micronaire values in cotton plant. Potassium is directly involved in the physiology of fiber elongation and thickening, thus $\mathrm{K}$ deficiency reduces micronaire, strength and length. The effect of potassium on fiber quality has been reported inconsistent across the study period. Pettigrew (2003) found that plants grown at $0 \mathrm{~kg} \mathrm{~K} \mathrm{ha}^{-1}$ produced lint with low micronaire and no fiber strength differences among different $\mathrm{K}$ treatments. Pettigrew et al. (1996) reported a drastic reduction in the length and micronaire quality on $\mathrm{K}$ deficiency.

\subsection{Effect of $\mathrm{N}$ and $\mathrm{K}$ interaction on cotton}

A significant interaction effects were reported for seed cotton yield, gin turnout, boll weight, boll numbers per plant, fiber strength and micronaire. This $\mathrm{N}^{*} \mathrm{~K}$ effects was also supported by significant linear regression coefficients. Significantly higher yield was reported in the treatment containing $60 \mathrm{~kg} \mathrm{~N}$ $\mathrm{ha}^{-1}$ without $\mathrm{K}$ and it shows superiority over the nitrogen and potassium control (Table 2, Figure. 1a). It was observed cotton seed yields were significantly increased with the application of $180 \mathrm{~kg} \mathrm{~N}$ combined with either 100 or $150 \mathrm{~kg} \mathrm{~K} \mathrm{ha}^{-1}$. The highest $\mathrm{N}$ application $\left(240 \mathrm{~kg} \mathrm{ha}^{-1}\right)$ tended to decrease yields. Potassium applications increased yields with $\mathrm{N}$ in both years. The linear K regression coefficient for seed cotton yield was significant in 2010 but not in 2011 (Figure. 2a). Among various tested combinations, the interaction between N180 and $\mathrm{K} 0$ had the greatest gin turnout while the lowest gin turnout was related to the interaction of N240 and K150 treatments (Figure. 1b). Maximum boll weights were obtained from N120 along with K50 to K200 treatments and also N180 along with K50 to K100 treatments. Further, Minimum boll weight was recorded at combination of N60 and K200 treatment (Figure. 1c). Maximum fiber strength values were related to the interaction between $\mathrm{N} 60$ and K200 treatments, and also the interaction between N240 and K0 treatments (Figure. 1d). Similarly, highest micronaire value was recorded at N120 and N180 together with K100 treatments while the lowest micronaire value was obtained at the highest $\mathrm{N}$ and $\mathrm{K}$ rate treatments (Figure. 1e).

\subsection{Correlation Coefficients at $\mathrm{N}$ and $\mathrm{K}$ Fertilization Treatments}

Positive relationships were found between total dry matter and fiber strength $\left(\mathrm{r}=0.947^{*}\right)$ and boll number per plant $\left(\mathrm{r}=0.908^{*}\right)$ in 2010 and 2011, respectively. A positive correlation was reported between gin turnout and micronaire $(\mathrm{r}=0.984 * *)$ in 2010 at nitrogen fertilization treatments while a negative relationships were found between micronaire and seed cotton yield $\left(r=-0.935^{*}\right)$, total dry matter $(r=-0.942)$, fiber length $(r=-$ $\left.0.910^{*}\right)$ and boll number per plant $\left(\mathrm{r}=-0.886^{*}\right)$. Vegetative growth and plant biomass were decreased under $\mathrm{K}$ deficient 
conditions (Kerby \& Adams, 1985), because potassium plays an important role in photosynthesis, accumulation and allocation of carbohydrates (Reddy \& Zhao, 2005). Micronaire is linearly related to the sufficient amount of carbohydrate supply for developing bolls provided by canopy photosynthesis (Bauer et al., 2000).

Similarly, a positive correlation was reported between total dry matter and seed cotton yield( $\left.\mathrm{r}=0.980^{* *}\right)$. Positive relationships were found between boll number per plant and seed cotton yield $(\mathrm{r}=0.963 * *)$ and total dry matter $(\mathrm{r}=0.990 * *)$ in 2010. Makhdum et al. (2007) reported positive significant correlations between seed cotton yield and total dry weight under the addition of $\mathrm{K}$ fertilizers in this manner results of present study are in agreement with the findings of these researchers. Negative relationships were found between micronaire and total dry matter $(\mathrm{r}=-0.882 *)$ and boll number per plant $\left(\mathrm{r}=-0.986^{* *}\right)$ at $\mathrm{K}$ fertilization treatments in 2011 . Higher boll loads or large number of bolls, create a greater demand for assimilates of each boll and increased competition may decrease the amount of cellulose available for each fibre and consequently lower the fibre micronaire (Kelly et al., 2008).

In 2011, significant correlation was found between total biomass production and seed cotton yield $\left(\mathrm{r}=0.900^{*}\right)$; between fiber length and total biomass production $\left(r=0.928^{*}\right)$. Significant and negative correlations were reported between micronaire and total biomass production $(r=-0.882 *)$, boll number per plant and micronaire $\left(\mathrm{r}=-0.986^{* *}\right)$ at $\mathrm{K}$ fertilization treatments. Findings of this study are contradictory to the findings of Clement et al. (2013), those who reported that there was no significant relationship between total biomass and fiber-quality parameters. The supply of potassium rates according to the linear regression model, increased seed cotton yield which varies from 2640 to $2971 \mathrm{~kg} \mathrm{ha}^{-1}$ and showing an increase of $10.2 \%$ with the higher potassium rate compared to the lowest rate in 2010 (Figure. 2a). Fritschi et al. (2003) described a quadratic relationship between micronaire and $\mathrm{N}$ treatment at one site and linear functions at the other site. Cotton biomass production response to $\mathrm{N}$ rates is linear which indicating that application of highest $\mathrm{N}$ rate did not maximize the biomass (Figure. 2b) under the conditions of this experiment. A linear relationship between total dry matter accumulation and $\mathrm{K}$ rate was observed in 2010 and 2011.These strong relationships indicated a trend toward greater dry matter accumulation and partitioning into developing bolls with increasing $\mathrm{N}$ and $\mathrm{K}$ applications. As evident from this study showed overall lower plant assimilates levels caused lower total biomass which would help in the explaining the lower yields and poorer fiber quality in $\mathrm{K}$ plots.

The number of bolls per plant varied with the nitrogen and potassium rates, as in the linear regression model, increasing with the nitrogen and potassium supply from 60 to $180 \mathrm{~kg} \mathrm{~N}$ $\mathrm{ha}^{-1}$ and from 50 to $150 \mathrm{~kg} \mathrm{~K} \mathrm{ha}^{-1}$, respectively (Figure. 2c). Different $\mathrm{K}$ rates varied as regards the mike values, as in the linear regression model (Figure. 2e), the micronaire values decreased (from 5.4 to 5.1 ) as the potassium rates increased from 50 to $150 \mathrm{~kg} \mathrm{ha}^{-1}$ in 2010 . $\mathrm{N}$ rates also resulted in a linear response of fiber strength (Figure. $2 \mathrm{~d}$ ), which is in accord with Fritschi et al. (2003), who reported a significant effect of $\mathrm{N}$ on fiber strength. Fiber micronaire also revealed a linear reduction with increase the $\mathrm{K}$ levels ( $\mathrm{r} 2=0.92$, Figure. 2e), indicating negative association with $\mathrm{K}$ treatments.

\section{Conclusions}

Overall evaluation of the findings indicates that the best combination is $180 \mathrm{~kg} \mathrm{~N}$ along with $100 \mathrm{~kg} \mathrm{~K} \mathrm{ha}^{-1}$ appeared most appropriate and suitable for achieving higher yield and yield attributes in cotton. Positive yield responses to $\mathrm{K}$ applications suggested the importance of $\mathrm{K}$ application to the cotton crop in clay loam soil for optimum growth and high yield in the present study conditions, where conventional management practices have usually applied excessive amounts of $\mathrm{N}$ while not considering $\mathrm{K}$ fertilization because it is thought that the soils of Turkey are rich in $\mathrm{K}$ and no need application of $\mathrm{K}$ fertilizer. Consequently, it can be suggested that N180 and $\mathrm{K} 100$ or $\mathrm{K} 150 \mathrm{~kg} \mathrm{ha}^{-1}$ can be suitable fertilizer management practice for cotton production in experimental and similar environments.

\section{Conflict of interest}

Authors would hereby like to declare that there is no conflict of interests that could possibly arise.

\section{References}

Bauer PJ, Roof ME (2004) Nitrogen, aldicarb, and cover crop effects on cotton yield and fiber properties. Agronomy Journal 96: 369-376. doi:10.2134/agronj2004.3690.

Bauer PJ, Frederick JR, Bradow JM, Sadler EJ, Evans DE (2000) Canopy photosynthesis and fiber properties of normaland late-planted cotton. Agronomy Journal 92:518-523. doi:10.2134/agronj2000.923518x.

Berberoglu F, Karaltın S (2001) Farklı azot ve fosfor dozlarının Maraş 92 pamuk cesidinde (Gossypium hirsutum L.) verim ve fizyolojik özelliklere etkisi. Türkiye 4. Tarla Bitkileri Kongresi, Cilt: II, 345-349, 17-21 Eylül.

Cassman KG, Kerby TA, Roberts BA, Bryant DC, Higashi SI (1990) Potassium effects on lint yield and fiber quality of Acala cotton. Crop Science 30: 672-677. doi: 10.2135/cropsci1990.0011183x003000030039x.

Clement JD, Constable GA, Conaty WC (2013) $\mathrm{CO}_{2}$ exchange rate in cotton does not explain negative associations between lint yield and fiber quality. Journal of Cotton Science 17: 270278.

Colakoğlu H (1980) Nutrient requirement and fertilization of cotton in Turkey. Potash Review 12: 3. 
Cope JT (1981) Effects of 50 years of fertilization with phosphorus and potassium on soil test levels and yields at six locations. Soil Science Society of America Journal 45: 342347. doi:10.2136/sssaj1981.03615995004500020023x.

EL Sabagh A, Abd El-Rasool S, Islam MS, Barutçular C, Omar A (2016) improving growth of canola (Brassica napus L.) plants by seed inoculation and inorganic - organic nitrogen fertilization. Asian Journal of Science and Technology 7 : 2283-2288.

Fritschi FB, Bruce A, Roberts A, Travis RL, Rains DW, Hutmacher RB (2003) Response of irrigated Acala and Pima cotton to nitrogen fertilization: growth, dry matter partitioning and yield. Agronomy Journal 95: 133-146. doi:10.2134/agronj2003.1330.

Gormus O, Yucel C (2002) Different planting date and potassium fertility effects on cotton yield and fiber properties in Cukurova region, Turkey. Field Crops Research 78: 141149. doi: 10.1016/S0378-4290(02)00121-1.

Johnston AE, Milford GFJ (2012) Potassium and nitrogen interactions in crops. Rothamsted Research, Harpenden, Hertfordshire AL5 2JG.

Karademir C, Karademir E, Doran I,Altıkat A (2006) Farkliazot ve fosfor dozlarınınpamuğun verim, verim bilesenleri ve bazı erkencilik kriterlerine etkisi. Tarım Bilimleri Dergisi 12 : 121-129.

Keller T (1997) Fiber properties as components of cotton yield: The 1996 Arkansas Study. USDA NASS Research Report No. RD-97-03.

Kelly D, Bange M, Constable G (2008) Unravelling the micronaire challenge. The Australian Cotton Grower. Ooctober-November 2008 pp. 24-26.

Kerby TA, Adams F (1985) Potassium nutrition of cotton. In: R.D. Munson (ed.) Potassium in Agriculture. ASA Madison, WI, pp.843-860.

Kumar J, Arya K C, Sidduqe M Z (2011) Effect of foliar application of $\mathrm{KNO} 3$ on growth, yield attributes, yield and economics of hirsutum cotton. Journal of Cotton Research and Development 25: 122-123.

Lokhande SB, Reddy KR (2015) Cotton reproductive and fiber quality responses to nitrogen nutrition. International Journal of Plant Production 9: 191-209.

Makhdum MI, Pervez H, Ashraf MI (2007) Dry matter accumulation and partitioning in cotton $(G$. hirsutum $L$.) as influenced by potassium fertilization. Biology and Fertility of Soils 43 : 295-301. doi: 10.1007/S00374-006-0105-6.
McConnell JS, Glover RE, Vories ED, Baker WH, Frizzell BS, Bourland FM (1995) Nitrogen fertilization and plant development of cotton as determined by nodes above white flower. Journal of Plant Nutrition 18 : 1027-1036. doi:10.1080/ 01904169509364958.

Mert M, Calıskan ME, Günel E (1999) Farklı azot dozlarının pamuğun tarımsal ve teknolojik ozelliklerine etkisi. Türkiye 3. Tarla Bitkileri Kongresi, 15-18 Kasım, (I): 109-114, Adana.

Mullins GL, Burmester CH (1991) Dry matter nitrogen, phosphorus, and potassium accumulation by four cotton varieties. Agronomy Journal 82: 729-736. doi: 10.2134/agronj1990.00021962008200040017x.

Pettigrew WT, Heitholt JJ, Meredith Jr WR (1996) Genotypic interactions with potassium and nitrogen in cotton of varied maturity. Agronomy Journal 88: 89-93. doi: 10.2134/agronj1996.0002196208800010019x.

Pettigrew WT, Meredith WR Jr (1997) Dry matter production, nutrient uptake, and growth of cotton as affected by potassium fertilization. Journal of Plant Nutrition 20: 531-548. doi: 10.1080/01904169709365272.

Pettigrew WT (1999) Potassium deficiency increases specific leaf weights and leaf glucose levels in field grown cotton. Agronomy Journal 91: 962-968. doi: 10.2134 / agronj1999.916962x.

Pettigrew WT (2003) Relationships between insufficient potassium and crop maturity in cotton. Agronomy Journal 95: 1323-1329. doi: 10.2134/agronj2003.1323.

Pettigrew WT, Meredith WR, Young LD (2005) Potassium fertilization effects on cotton yield, yield components and nematode populations. Agronomy Journal 97: 1245-1251. doi: 10.2134/agronj2004.0321.

Read JJ, Reddy KR, Jenkins JN (2006) Yield and fiber quality of upland cotton as influenced by nitrogen and potassium nutrition. European Journal of Agronomy 24: 282-290. doi: 10.1016/j.eja.2005.10.004.

Reddy KR, Zhao D (2005) Interactive effects of elevated CO2 and potassium deficiency on photosynthesis, growth and biomass partitioning of cotton. Field Crops Research 94: 201213. doi: 10.1016/j.fcr.2005.01.004.

Reddy KR, Koti S, Davidonis GH, Reddy VR (2004) Interactive effects of $\mathrm{CO} 2$ and $\mathrm{N}$ nutrition on cotton growth, development, yield and fiber quality. Agronomy Journal 96: 1148-1157. doi: 10.2134/agronj2004.1148.

Tewolde H, Fernandez CJ (2003) Fiber quality response of Pima cotton to nitrogen and phosphorus deficiency. Journal of Plant Nutrition 26: 223-235. doi: 10.1081/PLN 
Tozan S (1990) Büyük menderes havzası topraklarında azot, fosfor ve potasyum gübrelerinin pamuğun topraktan kaldırdıgı besin maddesi miktarları ve bazı lif kalitesi üzerine etkileri. Doktora tezi, Ege Üniversitesi FBE, Izmir.

Wang YH, Zheng M, Gao XB, Zhou ZG (2012) Protein differential expression in the elongating cotton (Gossypium hirsutum L.) fiber under nitrogen stress. Science China 55 : 984-992. doi: 10.1007/S11427-012-4390-2.

Wu FB, Wu LH, Xu FH (1998) Chlorophyll meter to predict nitrogen side dress requirement for short season cotton. Field Crops $\quad$ Research 309-314.doi:10.1016/S03784290(97)00108-1.
Yang JS, Hu W, Zhao W, Meng Y, Chen B, Wang Y, Zhou Z (2016). Soil potassium deficiency reduces cotton fiber strength by accelerating and shortening fiber development. Scientific Reports 28: 28856. doi: 10.1038/srep28856.

Zhao D, Oosterhuis DM, Bednarz CW (2001) Influence of potassium deficiency on photosynthesis, chlorophyll content and chloroplast ultrastructure of cotton plants. Photosynthetica 39 : 103-109. doi: 10.1023/A:1012404204910

Zhao S, Wang C, Segarra E, Bronson K (2010) Multidimensional quality attributes and input use in cotton. Beltwide Cotton Conferences New Orleans, Louisiana, Jan. 47. 